\title{
Institutions and the organisation of stability and violence
}

\author{
Jan Koehler and Christoph Zürcher
}

\section{Post-socialist turmoil in Yugoslavia and in the Caucasus}

I $\mathrm{N}$ THE CAUCASUS and in Former Yugoslavia the collapse of the socialist empires has caused more hot conflicts and wars than in any other transition region. In each region there were four major armed conflicts. In the Caucasus, there was the disagreement between Armenians and Azeris over Nagorno-Karabakh (1988-93: no political settlement); the wars about Chechnya (1994-96 and 1999-today: no settlement); the internal war in Georgia (1991-92) and Georgia's war with breakaway Abkhazia (1992-93: no settlement); and breakaway South-Ossetia (1989-92: no settlement).

In Yugoslavia, the four major violent conflicts were the short campaign of the Yugoslav Army against the breakaway republic of Slovenia in June 1991; the wars between Croats and Serbs in eastern Slovenia and in the Krajina (1991-95); the war in Bosnia-Herzegovina (1992-95); and the war about Kosovo, which was fought on the one hand between Serbs and Kosovo-Albanians in Kosovo, and on the other hand between NATO and Serbia (1998-99).

Both the Caucasus and Former Yugoslavia are typical high-risk regions. At least four factors commonly held responsible for increasing the risk of violence are present. ${ }^{1}$ First, there is the legacy of the socialist system of ethno-federalism (Brubaker 1994; Bunce 1999). Socialist ethno-federalism had linked territories with a titular nation and provided these territories with quasi-state institutions, such as citizenship, borders, symbols, political institutions, and in the case of Yugoslavia, armed forces. Ethno-national mobilisation for independence was thus prepared by the socialist systems. Secondly, in most cases there was also a past history of grievance and conflicts. Armenians and Azerbaijanis, Chechens and Russians, Serbs and Kosovars, Croats and Serbs all have stories and experiences of old animosity. Thirdly, the peoples of Yugoslavia and the USSR experienced economic hardships during the 1980s. Lastly, all polities in Yugoslavia and in the Caucasus (that is, the former Federal Republics and the former 
Autonomous Republics) are multi-ethnic territories with a complex ethnic geography.

As a result, there is a wide array of conflict potential in both regions. However, far from all potential conflicts turned into violent conflicts. In other words, similar permissive conditions do not always and not automatically translate into violent conflicts. In the Caucasus, the most surprising case of stability against all odds is Dagestan (see Chapter 6 in this volume). Despite the fact that this tiny mountainous Republic is home to more than thirty national groups, borders war-torn Chechnya and suffers from dramatic economic deprivation, it has managed to avoid large-scale internal violence. But also in Yugoslavia, there are cases of stability against all odds. Voivodina, Montenegro and, until 1999, also Macedonia are such examples.

By comparing Yugoslavia and the Caucasus, differences in the intensity and scale of conflicts may be observed. Fighting in Yugoslavia, as a rule involved more armed people, and more civil victims. This may partly be explained by structural differences between Yugoslavia and the Caucasus, namely by the different structures of the federations, and by the way in which the federal centre was dismantled by the federal units.

In Yugoslavia during the 1980s, the most powerful of the Republics, Serbia, tried to usurp the position of the dwindling federal Yugoslav centre. When it became obvious to the Serbian leaders that they would not be able to hold together the federation, under the leadership of Slobodan Milosevic they switched to a nationalist agenda, trying to secure a 'greater Serbia' at the expense of the territorial integrity of Croatia and later Bosnia-Herzegovina. This triggered wars between nationalising states, although these wars were, as in the Krajina, in east Slovenia and especially in Bosnia, mainly fought by the proxies-the ethnic groups.

By contrast, in the USSR, it was Russia - by far the most powerful republicthat actively opposed (under Yeltsin's leadership) the restoration of the Union. Russia thus became, for a certain period, the natural ally of the breakaway republics. This explains the smooth and relatively peaceful dissolution of the USSR. Secondly, Russia itself is a multi-ethnic federation. Russia's state ideology is not based on Russian (russkii) ethno-nationalism, but on the multi-national Russian (rossiiskii) state. The Russian Federation was thus able (with the dramatic exception of Chechnya) to contain and defuse ethnic tensions within its territory.

In the South Caucasus, however, the patterns of conflict are similar to those in Yugoslavia. Here, the nationalising process of Georgia, Armenia and Azerbaijan was met with similar nationalising processes in the territories of minority groups within these states. The conflict between breakaway NagornoKarabakh and Azerbaijan stopped short of turning into an official inter-state war between Azerbaijan and Armenia and was accompanied by ethnic cleansing on all sides. In Georgia, the nationalising Georgian state was challenged by two 
ethno-national secessionist movements, in Abkhazia and South-Ossetia, which spiralled into wars accompanied by ethnic cleansing.

\section{Violence, transition and state weakness}

Between 1989 and 1991, both federations imploded. How was the emergence of organised violence visible both shortly before and after the break-up linked to this extreme form of state weakness?

The systemic transition that occurred in Yugoslavia and the USSR can be depicted as rapid institutional change, accompanied by a breakdown of hierarchies and by the loss of the state's sanction capacities. Systemic transition increases the risk of violence. Two mechanisms account for this: first, when the state loses its sanction capacity, the costs for breaking the rules fall. Secondly, in situation of transition, the premium for the winner is extremely high, because the winner takes all: what is at stake during transition is essentially the right to write the new rules. The future is at stake. In short, during transition, the costs for breaking the rules and organising violence sink, while the booty is 'fattened' (see Chapter 12 in this volume). The risk for socially 'dis-embedded', violent competition increases. ${ }^{2}$

These mechanisms apply to competition between all sorts of societal actors in transition societies. Relevant for the study of organised violence are, however, two arenas: first, the competition on the ground between two or more ethnic groups within a multi-ethnic polity. Notably, all Yugoslav and Soviet polities (that is, the first-order, Republics and the second-order Autonomies) are multi-ethnic polities.

Secondly, these mechanisms also apply for the competition between incumbent political elite and challenging political elite. Systemic transition always opens up opportunities for political newcomers to challenge incumbent leaders. During such intensified competition, actors may seek to use all available resources. The mobilisation of support by instrumentalising ethnicity can be one of the available strategies. This is, however, a very risky strategy, since it implies the promotion of a negative and threatening perception of the 'Other'. Ethnoradical mobilisation promotes fears of exclusion or even physical destruction, and can thus easily spin out of control.

A second threat to societal stability that comes with transition, state weakness and elite power struggles is the emergence of parallel and competing political institutions. When the entry into existing political institutions is blocked, challengers often create new, alternative ad hoc institutions. For example, challengers in Chechnya, Azerbaijan, Armenia and Georgia founded popular national movements. At a certain time, these alternative institutions were assigned so much political power that a situation of parallel power emerged: the formal socialist institutions, in the first place the Party and the Supreme Soviets, were opposed by organised national movements. In Armenia, in a relatively swift 
and constitutional move, the challengers took over the state and consolidated the new regime. In Chechnya, Georgia and Azerbaijan, however, the competition between the socialist institutions and the newly founded challenging institutions (the 'Popular Front' in Azerbaijan, 'Round Table/Free Georgia' in Georgia and the 'Chechen National Congress' in Chechnya) led to internal instability and eventually to internal war.

State weakness can cause violence. Therefore, it may be assumed that rebuilding state capacities must be a high priority of new leaders. A quite unexpected lesson to be learned from the study of organised violence in Yugoslavia and the Caucasus is that this assumption is not necessarily true. This lesson pertains in the first place to unrecognised would-be states (the formally secondorder units). Abkhazia, South-Ossetia, Chechnya and Kosovo have made no significant progress towards strengthening their state capacities, despite their aspirations for sovereignty (Nagorno-Karabakh has to be regarded as an exception because of its very close informal integration with the Armenian Republic). It is argued here that this is not a paradox, but can be the rational strategy of a political elite: international legal sovereignty is a valuable resource. Establishing state capacities, with functioning state bureaucracies, however, is expensive, risky and can even contradict the interests of elites. All of these 'statelets' are governed by highly institutionalised networks of patronage. In order to stabilise these networks, the patrons of the networks have to satisfy the needs of their clientele. Not surprisingly, patrons in such weak network-states usually control access to resources. In order to secure their position, the patrons must prevent access to resources to potential challengers and hinder independent activities outside the network. Therefore, patrons will minimise public goods such as safety, protection, economic opportunities or legal protection; instead they will try to privatise these goods and to make them available only within the network. Patrons artificially minimise public goods. One means of achieving this is by keeping the state weak; another means is by tolerating or even promoting lowlevel conflict, even within their own state, since this increases insecurity and thus maximises the dependency of political actors (and the population) on the patron's good will. State weakness may thus even be the rational choice of leaders, who base their rule on networks of patronage (see Mappes-Niediek's Chapter 5 on Kosovo; Baev's and Christophe's Chapters 7 and 10, respectively, on Georgia; Koehler and Zürcher's Chapter 8 on Azerbaijan, Armenia and Nagorno-Karabakh; and Kisriev's Chapter 6 on Chechnya, in this volume).

\section{Institutions matter}

What accounts for the different ways the various post-socialist societies dealt with the stress of transition? The case studies in this volume look at the institutional framework of these societies for answers. It is argued here that institutions 
perform three functions which are relevant for the organisation of stability and violence:

First, institutions are accepted, trained and sometimes enforced patterns of interaction which 'embed' conflict. Institutions process competing interests: they offer rules and procedures for the articulation of interests, they provide for a flow of information between actors and they offer binding procedures for determining the outcome of interaction. Institutions, particularly official state institutions, are usually 'protected' - the state has the means to punish defiance. Violation of the procedures is thus expensive as long as the state has the capacity and the will to sanction defiance. The breakdown of such a framework lets conflict spin out of the framework that a society has designed in order to deal with conflicts. Conflict potential may then turn into escalated, violent conflict. The fact that a society has institutionalised procedures for dealing with conflicts in place does not mean that there is no conflict within the society. Conflicting interests are the normal state of affairs in every society. ${ }^{3}$ Competing interests can be processed according to accepted rules or according to unregulated power. Internal fragmentation and violence is thus not a result of competing interests, but of unregulated, dis-embedded processing of competing interests.

Secondly, in general the institutional framework provides the incentive structure for actors. The costs of organising violence depend on the institutions at work. When the institutional framework of a society is such that the organisation of violence is cheap, then the risk of conflict increases. When, on the contrary, institutions increase the cost of violence, the risk decreases. In other words, it depends on the design of the institutional framework whether institutions defuse or diffuse violence. A case in point is the socialist system of ethnofederalism. This system, originally designed for processing potential tensions between national groups has, once the tight control of the party weakened, promoted secessionist conflicts and inter-group violence. The socialist system of ethno-federalism has prepared the quest for sovereignty and independence of the federal subjects of Yugoslavia and of the USSR. Ethno-federalism provided the subjects with a set of political institutions such as borders, symbols, a constitution, citizenship, parliaments, media, educational system, a titular nation and a national elite. All these prerequisites of statehood were well in place at the time that the empires broke down. Thus, the cost of state building was relatively low, and the national elite in the republics opted for independence. Likewise, the national elite of the second-order units (the so-called Autonomous Republics) opted for independence from 'their' republics. Not surprisingly, the borders of the second-order units mark the hot spots in Yugoslavia and the Caucasus - in Nagorno-Karabakh, South-Ossetia, Abkhazia, Chechnya and Kosovo.

Thirdly, institutions have distributional consequences. They structure access to resources and define, 'who gets what' in society. The relative power of 
actors in a society thus depends on the institutional framework. Changes of the institutional framework, accordingly, also have distributional consequences. When institutions cease to work, for example when the state loses its sanction capacity, then the old elite may lose access to resources, or challengers may gain access to resources. This shift in the relative power of 'incumbents' and 'challengers' may lead to an intensified struggle for power. The risk that this competition spins out of control is high, when the sanction power of the state is weakened. Institutions not only regulate access to resources, they are per se a resource. Institutions are a set of rules, and some of them have a considerable organisational power. Those who control bureaucratic or military hierarchies, parties, clan networks or networks of patronage can use the organisational power of these institutions in order to mobilise support.

\section{Institutional framework and local know-how}

Evidence from the case studies suggests that the presence of risk factors on the ground and the collapsing central state alone cannot explain the variance that may be observed across Yugoslavia and the Caucasus with regard to violent or non-violent social outcome.

An explanation of this variance in the institutional framework of these societies has been sought. But which institutions matter? Social spaces are veined with numerous rules and procedures; stability and violence are consequently a social outcome of many institutions intertwining. There is not and cannot be a general answer to the question which institutions matter, as this may vary significantly from case to case: however, the chapters in this volume present some road signs. First, the usual suspects matter: the formal political institutions of a polity - parliaments, presidency, election laws, parties, property rights or administrative divisions - are important. Significant parts of formal institutions of the USSR and the Yugoslav Federation survived the demise of the central state and were and still are of consequence. The importance of the administrative-territorial division of the ethno-federations has already been stressed. Other important legacies of the socialist system are the party structure and the socialist rubberstamp parliaments, which acquired real influence during the course of transition. In fact, internal cohesion or internal fragmentation depended a lot on how and by whom these institutions were reused. When elites use existing, 'trained' institutions for conquering or keeping the state, the risk of social fragmentation is lower than when elites invent new institutions, such as round tables, popular fronts, or national congresses. For example, the communist apparatchik Milosevic rose by taking over the organisational potential of the Serbian Communist Party and reusing it for his nationalist agenda. The key to his 'success' was combining two central resources of post-socialist spaces, namely the mobilising power of ethnicity and the organisational power of party structures. The price for Serbia's 
internal stability was paid, however, by its neighbours, because Milosevic proved to be very skilful at externalising conflicts.

An analysis of the institutional framework of society must not be limited to formal state institutions. In challenging widespread state-centric approaches, it has been argued here that the institutional framework of post-socialist societies consists not only of the institutional legacy of 'official' state institutions, but also of the 'shadow' institutions that have emerged as a response to the organisational voids of socialism, and of those locally rooted traditional norms and conventions that survived in the organisational voids of the socialist state. These three analytically distinct sets of institutions - the 'formal', the 'shadow' and the 'traditional'- form together a hybrid, locally distinct framework, which structures incentives, opportunities and constraints of actors on the ground.

The existence of a locally distinct, colourful and largely informal set of institutions clearly contradicts the superficial picture of homogeneous, centralised socialist states fostered by many outside observers, ruling elites and dissident intellectuals alike (compare Hann 1996: 7-10). All chapters in this book stress the fact that the socialist societies were at least in the last decade of their existence socialist only in form, but informal and locally distinct in content.

The socialist state in its last two decades was a rather weak state, although its vertical command lines were functional until the late 1980s. The social institutions compensating for (or simply exploiting) the failures, voids and weaknesses were informal, often even illegal, since the blueprints of the socialist state did not foresee societal organisation outside the realm of the state's control.

These unofficial institutions went largely undetected by political science and sovietology, which focused mainly on 'official' state institutions. Again, it is impossible to name which of these 'shadow' institutions are in general relevant for the explanation of violence. But here, too, road signs exist, and the chapters in this book present some evidence.

Of the issues with which this book is concerned, the most significant organisational void of the socialist state was that it formally banned all open social conflict. On the other hand, it relied on social self-organisation to fill the gaps. Instead of founding its legitimacy on setting the general rules for local institutions regulating conflict, the state condemned those institutions to the shadows of informality or even criminality. Thus conflict was socially embedded in the informal sector but not institutionalised by official state institutions.

By denying the existence of the conflicting interests of social groups the state was unable to provide a framework of checks and balances between identity groups or socio-professional lobbies in a given administrative unit. Competing interests were pushed beneath the official surface and were accordingly dealt with by informal bureaucratic barter at the few 'switchboards' of decision making. Minority groups had therefore no official channels for lobbying their real or perceived grievances. Even lobbying for a change in administrative status 
(like in Kosovo in the late 1970s or in Nagorno-Karabakh on repeated occasions over the decades after the death of Stalin) had to be organised via informal channels and was usually aimed directly at the corridors of power in the centre, thus bypassing the formal political institutions. The failure of the state to provide for official arenas in which identity groups (here the titular nation and a minority) were able to settle their disputes by procedures aggravated the tendency of radicals of such groups to retreat to what Elwert called 'informational isolates' (Elwert 2001a). This in turn increases the risk of future violent conflict, since these informational islands breed radical and exclusive views of the other group.

One species that grew especially well in the organisational voids of the socialist state were omnipresent networks of patronage (cf. Willerton 1992). After the collapse of the central state, these networks became, in many places, the most cohesive institutional structure, substituting state tasks and concentrating political power and economic resources.

The most powerful and relevant informal networks developed in the shadow of the official socialist institutions and were usually closely linked to administrative functionaries who, by virtue of their official position, had the power to allocate resources, privileges and protection to their clientele. Often, patrons of such networks were the provincial 'strong men' which Koehler and Zürcher in Chapter 8 in this volume call apparatchiki-biznesmeny. After the collapse of empire, many of these apparatchiki-biznesmeny smoothly turned into biznesmenypatrioty. It has been shown in another study that in all cases of organised violence in the Caucasus, the financial resources that are needed for the-expensive - organisation of violence came from the Soviet 'shadow' economy (Zürcher, Koehler and Baev, 2002). The biznesmeny-patrioty that have grown rich in the shadow economy were the most important financiers of the wars in the Caucasus. Raufer and Mappes-Niediek in Chapters 3 and 5, respectively, in this volume reach similar conclusions with regard to the war in Kosovo.

Networks of patronage and trust were especially well suited to exploiting the opportunities that the booming shadow economy of the late socialist state offered the entrepreneurially minded (on the scope and growth of the shadow economy in the former USSR see Baev's Chapter 7 in this volume). Often such networks were built around clans and neighbourhoods in order to inject the measure of trust and cohesion that a successful exploitation of the opportunities of the socialist economy requires. Thus, as a by-product of generating trust, many networks developed an ethnic flavour. Often informal economic activity thus became ethnicised, and the competition for scarce resources was structured by ethnic belonging (see Koehler and Zürcher's Chapter 8 on Nagorno-Karabakh in this volume).

The border between networks of patronage designed for the exploitation of the 'shadow' economy and outright criminal networks is blurred, since all economic activities outside the planned economy of the state were by and large 
illegal. ${ }^{4}$ In addition, one activity of criminal networks in the late socialist state, apart from taxing the informal economy, was to provide services for the apparatchiki-biznesmeny such as protection, contract-security and mechanisms of enforcement or sanction. ${ }^{5}$ There is little comprehensive research on organised crime in the late socialist state, but evidence suggests that organised crime played an important role in resource generating and organising violence. Koehler and Zürcher's Chapter 8, Baev's Chapter 7, Mappes-Niediek's Chapter 5 and Raufer's Chapter 3 in this volume all support this assumption. They also lend credibility to the notion that closely-knit ties based on kinship with a high degree of exclusiveness were well suited to the organisation of criminal activity. In the former USSR and in former Yugoslavia such normative frames of reference, referred to as 'amoral familism'6 (Schwandner-Sievers 1998 on Albania), could be found as a parallel legal code in remote regions of Chechnya in the North Caucasus, Abkhazia and Svanetia in the Southern Caucasus and in Montenegro and Kosovo. Under conditions of increasing physical and social mobility (as in growing diaspora communities in remote cities) the exclusive code of such smallscale identity groups sometimes became relevant for the effective organisation of mafia-like criminal networks (see Raufer's Chapter 3 on Kosovo in this volume; compare Jamieson and Silj 1998: 20-39)

Finally, in the organisational voids of the late socialist state a colourful patchwork of 'traditional' institutions may be found, dealing with conflict and negotiating justice and access to resources which had survived socialist homogenisation. 'Traditional' institutions are presented here as local institutions without official character that use narratives of traditional depth as a resource for legitimacy.

Kisriev's Chapter 6 on Dagestan in this volume provides an illuminating example. Stability against all odds in multi-ethnic Dagestan can be explained by the existence of the system of dzhamaat. In Dagestan, 'dzhamaat' denotes a solidarity group, based primarily on neighbourhoods and not on ethnicity that has been in existence since the fifteenth century. In today's Dagestan, the dzhamaat forms the core political unit and performs many functions that in western democracies are performed by political parties. Dagestan's constitution and electoral law reinforces the importance of the dzhamaat: in Dagestan, only single-mandate electoral constituencies exist, and in each constituency only representatives from one ethnic group can run in elections. Political competition on the local level thus takes place between dzhamaats, but not between ethnic groups. Thus, the 'traditional' institution of dzhamaat and formal political institutions intertwine and produce societal stability. This example also demonstrates that even in weak states conflict can be effectively socially embedded over long periods of time, thanks to the division of labour between official and informal institutions. 


\section{Violent conflict as dynamic process}

Conflict escalation and de-escalation is, rather than a temporal sequence of different phases in time, a dynamic process, during which the rationales of the conflicting parties and the incentive structures that govern their action undergo dramatic changes. The initial rationales of a dispute may thus be very different from those that actually trigger the conflict and from those that eventually lead to either the stabilisation of a violent environment or to a departure from violence.

Generalising the material presented in this book, four different stages of the conflict process may be identified, called here 'dis-embedding conflict', 'markets of violence', 'ending violence' and 're-embedding conflict.'

\section{Dis-embedding conflict}

'Dis-embedding' is the process whereby conflict spins out of the socially constructed bonds designed to deal with it. There are four significant markers that accompany the dis-embedding of conflict, and each in its own right may serve as an early warning indicator: the loss of the binding power of official institutions; the loss of the state's legitimate monopoly of violence; access to resources for organisers of violence; and the emergence of organised groups that partly substitute the state.

The loss of the binding power of official institutions for the relevant groups in society has been a latent condition in the late socialist state. The socialist state, rather than provide for institutionalised procedures for dealing with conflicts over resources or positions, has pushed social conflicts into the informal sphere. As a result, official state institutions were detached from the relevant spheres of society's self-organisation. Parallel institutions developed or were empowered to back up functions not provided by the state. The weaker the legitimacy of state institutions became, the stronger the capacity and legitimacy of the parallel structures in place grew. This interdependency between the state and its competitors is most straightforwardly demonstrated in the performance of the Serbian state and the reaction of the Albanian community in Kosovo (see MappesNiediek's Chapter 5 in this volume).

The second factor that marks the dis-embedding of conflict is the loss of the state's legitimate monopoly of violence. Chapters 5, 7, 8 and 2 on Kosovo, Georgia, Nagorno-Karabakh and Bosnia, respectively, in this volume demonstrate that the state's monopoly of violence is not only endangered by dwindling state capacities; actually, they indicate that the real threat to the state's monopoly of violence is the loss of its legitimacy to use it. Legitimacy may break down owing to unpredictable or regular misuse of the state monopoly (as was the case of the Soviet state in Armenia, Azerbaijan and Georgia) or when it is taken over by one social force that is party to a conflict. A case in point is the attempt to take 
over the Yugoslav structures (above all, the army) by Serbian nationalist forces. Grandits and Leutloff's Chapter 1 in this volume describes this process from a local perspective in the case of the Krajina.

This loss of legitimacy of the central state was not, with the possible exception of Armenia in the Caucasus and Serbia in Former Yugoslavia, successfully backed up anywhere by the enforcement bodies of the newly independent states. They were seen either as party to the conflict (from the perspective of internal breakaway 'statelets' like Krajina, Nagorno-Karabakh or Abkhazia) or utterly ineffective and atomised beyond any central state control (most dramatically in Azerbaijan and Georgia until 1995).

A third factor that speeds up the dis-embedding of conflict is access to the three resources necessary for the organisation of violence, namely finance, manpower and weapons. The socialist 'shadow' economy provided enough opportunities to the biznesmeny-patrioty to acquire the necessary funds and channel them into the organisation of violence. Other sources of income stem from the diaspora and the profits from international crime, demonstrated in the case of Kosovo in Raufer's Chapter 3 in this volume.

Access to weapons is a second significant factor. Mappes-Niediek's Chapter 5 on Kosovo in this volume shows how rapidly the relatively stable and nonviolent situation changed once cheap automatic firearms were available from the storehouses of the failing Albanian state. In the Caucasus, weapons came in very large quantities from the storehouses of the disintegrating Soviet Army. Both the newly independent states and challenging rebel formations had no problems in arming themselves with cheaply bought or easily stolen Soviet weapons.

The third factor that helps dis-embed conflict is manpower. The organisation of violence requires the existence of groups of young men ${ }^{7}$ detached from state control or the gerontocratic social control of their families. The latter seems very likely in situations where the traditional family structure is either unable to secure a future career (be it official, informal or criminal) for their young males, or young men perceive the participation in gangs outside social control as a real short-cut to access resources traditionally controlled by the older generation. Mappes-Niediek's Chapter 5 in this volume shows the relevance of this condition for Kosovo. The breakdown of social control over young men and weapons has also been a dramatic experience especially for the older generation in Chechnya between the two wars in the 1990s and during the Georgian troubles at the beginning of the 1990s (Koehler 2000: 48-50, 71-74).

Such groups are capable of organising violence only when they possess mechanisms for internal coordination and internal sanction. This is where the last indicator for 'serious trouble ahead' comes into the equation: the existence of gangs or networks, often set up initially by specialists of informal violence (like patrons of organised crime), is the last factor that marks the dis-embedding of conflict. There is a myriad of colourful personalities - most of them now dead or 
in prison - competing for dubious fame: for Albania, Raufer's Chapter 3 in this volume outlines the cases of Agim Gashi and Princ Dobroshi; from the Bosnian war, violence specialists like 'Arkan', 'Tuta', 'Stela' (Hedges 1996; Wood 2000); and 'Juka', 'Celo' and 'Caco' in Sarajevo (Schork 1994) were important in the initial phase of organising collective violence by mobilising armed youths and then merging business interests with the opportunities of the emerging market of violence. In Georgia, criminal authorities like Djaba Ioseliani and shady biznesmeny-patrioty like Tengiz Kitovani even succeeded in temporarily taking over the state (Koehler 1999). In Chechnya, Bislan Gantemirov, former militsioner (Soviet policeman) and entrepreneur in the 'shadow' economy, set up the first armed gang in Grozny that was to become the backbone of Dudaev's National Guard.

As stated above, the important characteristic of these groups is that they develop internal sanction capacities: defiance of the group's rules may then often be costlier for the young members than challenging the crumbling state's monopoly of violence. At the same time, such groups offer personal security, protection of private business and trust for their members and clients. In so doing, they may become a highly effective competitor for the weak state and partly substitute state functions.

The establishment of such groups, ready to exploit the new opportunities for acquiring resources of violence and further undermining the weakened legitimacy of the state monopoly of violence and the binding capacity of the official institutions, occurred at some stage in all the cases presented in this volume (explicitly in the conflicts in the Krajina, Kosovo, Georgia and around NagornoKarabakh). Those armed groups were made from different raw materials (criminal, ethnic, clan or neighbourhood networks of trust) and usually went under an ideological banner of patriotism, nationalism (as in most cases presented in this volume) or protection of the ethnic kin and freedom as general anti-state approach (as in the cases of Chechnya and Kosovo). As competitors for 'the heart of the state' they were already in place before violence escalated beyond state control.

Both Kisriev's Chapter 6 on Dagestan and Vasilieva's Chapter 9 on the greater part of the North Caucasus in this volume show that the disintegration of central statehood even where weapons are available does not automatically lead to violence spinning out of control. Local institutions in many cases proved capable of not 'dis-embedding' violence and kept evolving violent alternatives to the retreating central state under social control. There may well be other such cases in the Caucasus and in Former Yugoslavia - like Adjaria in Georgia, Ingushetia bordering Chechnya, Montenegro, the Voivodina and (until recently) Macedonia - in which violence has been kept in check by institutions other than the state.

However, the more striking process has the state disintegrating into an 
armed gang warfare (see the cases of Krajina (Chapter 1), Kosovo (Chapter 5), Herceg-Bosna (Chapter 2), Nagorno-Karabakh (Chapter 8), Chechnya (Chapter 6) and Georgia (Chapter 7) in this volume) and thus heralding the next stage of violent performance.

\section{Markets of violence}

Whatever the rationale for escalation may have been, sustained organised violence has a high probability of stabilising as what Elwert's chapter 12 in this volume describes as 'markets of violence'. According to Elwert, markets of violence are 'understood as economic areas dominated by civil wars, warlords or robbery, in which a self-perpetuating system emerges which links non-violent commodity markets with the violent acquisition of goods' (p. 221).

The implication of this development is that no matter what stimuli, noble ideas or justified grievances may have accompanied or even motivated the process thus far, collective organised violence develops its own systemic rules. Once violent conflict is institutionalised as a market of violence, then the process of dismantling state institutions can hardly be reversed. There may be no way back to the status quo ante. The institutionalisation of violence as an integral part of everyday life is a change in paradigm that brings along a set of new rules, new types of actors with distinct limits, choices, and rationales; the institutionalisation of a market of violence may be seen as a systemic border after which the rules that governed society are replaced by a completely different logic of action. From the local perspective of the people used to the former institutions, this process has to be perceived as destructive and even traumatic.

While the core of the conflict may still be socio-political, the strategic actions of the entrepreneurs of violence are increasingly structured by short-term economic gains. The organisation of violence is expensive, and sustained violence needs continuous investment. Therefore, entrepreneurs of violence engage in economic activities which characteristically combine legal business activities, organised crime and warfare. This economy tends to be integrated in transnational networks of trade and investment. Entrepreneurs of violence engage in drug or weapons trafficking, in kidnapping, extortion, or in taxing the second economy. Profits are reinvested, or kept in offshore banks. Gradually, short-term economic interests replace long-term political ones, and entrepreneurs of violence become interested in avoiding battles and sustaining profit.

Once a market of violence is established, there is a strong rationale for the warlords to stabilise the status quo. If government officials receive a share of the revenues from the market of violence (or are themselves embarking on warlord politics), they might also become interested in prolonging this violence. In such cases sustaining low-level violence becomes a rational objective of both, the 'rebels' and the 'state'. This view contradicts the commonly held view of 
prolonged conflicts as an 'unintended and anarchical outcome', and it also contradicts the official discourse of governments and rebels. Such a situation is characterised by the lack of real battles between soldiers and rebels. Both sides may pretend to fight a war, but neither side is determined to commit substantial resources in order to win and end the war.

The profit-orientated entrepreneur of violence is at first glance hard to distinguish from the politically motivated rebel. They may share the same political discourse on historical injustices and political motivations, recruit from the same pool of recruits und pursue similar military tactics. However, the profit-oriented entrepreneur of violence has a different ranking of priorities: the main rational is making economic profit. Profit-orientated entrepreneurs of violence go for absolute gains, while the political motivated rebel goes for relative gains vis-à-vis the state they are fighting.

Negotiating political solutions to conflicts with entrepreneurs of violence is difficult. Often they have no interest in ending violence because only the escalation of violence brought and kept them in the leading positions and enabled them to keep the loyalty of their armed followers by acquiring booty to redistribute. Entrepreneurs of violence may be very reluctant to agree to any peace settlement. A successful peace settlement may lead to the strengthening of the state and to the re-establishment of a state monopoly of violence. This in turn would destroy the biotope in which markets of violence blossom. In their view, peace settlements are bad for business. Once a conflict zone has turned into a fully developed market of violence, any political solution, even one that fully takes into account the original grievances that caused the conflict, is prone to fail. There are no political solutions for violence that is mainly motivated by private profits. Entrepreneurs of violence cannot be involved in a lasting (and maybe costly) peace settlement by granting political concessions to the group they pretend to represent, since this is not their first preference.

This is not to say that entrepreneurs of violence cannot, in principle, be involved in conflict regulation. But it is vital to understand that their first preference is to make absolute gains. Hence, they even might support a conflict regulation plan that weakens the 'rebel state', if it increases their profit. They can, in other words, be bought. The latter point was most likely relevant in Kosovo since the leaders of the KLA had reason to feel confident that they would play leading roles in post-Serbian Kosovo and retain significant access to profitable resources (not always of the legal kind, as pointed out by Raufer's Chapter 3 in this volume).

On the other hand, the most prominent warlords of Former Yugoslavia, Mladic and Karadjic had no options for political careers in a post-war Bosnia under the auspices of the international community. Consequently, in order to smooth the Dayton process, international negotiators put considerable effort into deconstructing them as possible negotiating partners before Dayton. 
All violent conflicts in Yugoslavia and the Caucasus developed for a certain period into markets of violence. In comparison to near 'ideal-types' of markets of violence like Afghanistan, Lebanon, Sierra Leona or the Democratic Republic of Congo this stage was, however relatively brief, except for Chechnya, which has been completely torn apart by rival entrepreneurs of violence after the defeated Russian army left in 1996. The second Russian intervention in 1999 has until now not managed to dry out this market of violence.

\section{Departure from violence}

How did the Caucasian and Yugoslav polities depart from large-scale, organised political violence? The first striking observation with regard to this question pertains to the remarkable differences between the Caucasus and the Balkans. In the Balkans, the military defeats of the Serbs in the wars in Bosnia and about Kosovo, which paved the way to the end of violence, were achieved only owing to decisive international intervention. Likewise, the current non-violent situation in Macedonia, Bosnia and in Kosovo and the attempts at reconstructing the state are borrowed from the international community. It was international military intervention that implemented a monopoly of violence. In Bosnia and even more so in Kosovo, state functions are de facto executed by the international community. Security and the suppression of violence are exercised by foreign troops and are not an achievement of internal organisation.

By contrast, in the Caucasus, there has been no military intervention by the international community, and the precarious stability in and between the postSoviet states and 'statelets' is a result of internal organisation and of coming to terms with the consequences of performances on the battlefield.

It is noteworthy that Russia, Georgia and Azerbaijan were all unable to win the wars against their secessionist regions. Nagorno-Karabakh, South-Ossetia and Abkhazia are de facto independent 'statelets', and so was Chechnya until the second Russian military intervention in 1999. On the other hand, none of the secessionist regions has been able to gain internationally recognised independence, and none has concluded a peace treaty with the state from which it seceded.

The military victories of rebel territories are statistically rather a rare occurrence, since the central state usually commands more resources than the challengers. In the Caucasus, the success of the breakaway territories may be explained by the weakness of the newly independent states. Both Georgia and Azerbaijan had to organise their state capacities from scratch. They were economically and politically weak states that lacked the resources for intensive warfare, their soldiers were badly trained and hardly motivated to fight a dangerous war in order to keep peripheral regions within the central state. In addition, both Georgia and Azerbaijan were plagued by internal power struggles. Finally, 
these wars took place in societies that are haunted by a very high level of corruption. When corruption is widespread - sometimes even the single most important source of income for the state administration - people from ministers and high-ranking officers to privates may profit from the state of war. They may then become interested in prolonging the state of war, but have no real interest in fighting, winning and ending the war. Thus, the violent contest between 'secessionist rebels' and 'states' in the Caucasus resembled the competition between two upstarts. In the wars of Azerbaijan against the breakaway NagornoKarabakh and Georgia against the breakaway Abkhazia and South-Ossetia, the 'rebel' upstarts proved to be much more efficient in organising violence (including resources form outside) than the 'upstart states' they challenged. Consequently, the 'rebels' won on the battlefield.

Departing from violence requires not only coming to terms with the neighbouring state or the neighbouring groups. It also requires the reconstruction of statehood and state capacities. The post-war polities must, in the first place, execute their legitimate monopoly of violence and integrate or neutralise those groups that have an interested in prolonging conflict.

In Kosovo, Bosnia and more recently Macedonia, this task has been largely outsourced. It is the international community that provides these territories with the most basic state capacities. By contrast, the post-war Caucasian polities had to master their internal post-war consolidation by themselves. A formidable challenge they had to meet was the neutralisation of entrepreneurs of violence returning from the battlefield and aspiring to take over leading positions in politics and business. Not all polities have mastered this task. The most dramatic failure was Chechnya. President Maskhadov's strategy of incorporating key players of the market of violence in his administration only sped up the process of disintegration. By the end of 1998, rivalling warlords had completely dismantled the few remaining state institutions and turned Chechnya into a market of violence.

More successful were the attempts at reconstructing statehood elsewhere. In Georgia and in Azerbaijan, the old guard of professional political patrons incorporated key players of the market of violence into state-run power agencies, only to neutralise or outmanoeuvre them at a later date. As it turned out, extensive Soviet-trained networks of patronage proved to be a resource strong enough to oust the warlords.

This, however, succeeded at the cost of opening significant shares of state resources to the ambitions of the old networks of patrons that guaranteed nonviolent stability and at the cost of empowering certain powerful agencies to act as state agents beyond the control of state (the police in Georgia, the army in Armenia and the presidential apparatus in Azerbaijan).

In the case of Armenia, where a dogmatic idea of common national cause with existential urgency remained a paramount integrating factor throughout 
the war, coming to terms with the returning victorious 'former truck drivers turned generals turned deputy ministers' proved to be a very serious and not always peaceful challenge. Here - as in Nagorno-Karabakh - the Soviet networks that managed to establish a stagnant stability in Azerbaijan and Georgia had a much harder time competing with, first, the new nationalist elite and then the entrepreneurs of violence returning victorious from the war in NagornoKarabakh. With the violent death of both the former First Secretary of the CP in Soviet Armenia and icon of Soviet patronage (Karen Demirchian) and the leading strong man (Prime Minister and former Minister of Defence, Vazgen Sarkisian) who were assassinated in the 1999 parliament massacre, a relatively new network of former politicians from neighbouring Nagorno-Karabakh was left to run the state (most prominently President Robert Kocharian and Minister of Defence Serzh Sarkisian).

\section{Re-embedding conflict}

The process of conflict spinning out of socially constructed bonds has been called 'dis-embedding'. Re-embedding means therefore taming conflict by (rebuilding) socially constructed bonds that reverse this process.

In the study of violent conflict the problem of institutionalising peace is usually not regarded as a dynamic social process in its own right, separate from the departure from violence. It is either treated as a problem of society after conflict, detaching the question of peace from the dynamics that ruled conflict before, or peace is simply treated as the absence of war.

The approach taken in this book has been different from the outset. By regarding conflict as a crucial, yet very common phenomenon in society the focus was shifted away from tale and content of the quarrel to the question of the institutional embedding of conflict in order to understand the processes of violent escalation or its containment in the Caucasus and Former Yugoslavia. 'Embedding' refers to a conflict being socially controlled by internalised norms and values and dealt with by the existing and reliable institutions a society has in place. The ability for adaptation to changing conditions and innovation proved essential for the societies in transition to keep conflict embedded and avoid passing the threshold of no return and sliding into an economy of violence.

Providing institutions and procedures for handling conflicts in a predictable way according to known rules is essential for the cohesion of a society and can actually be the foundation of the state's legitimacy (Luhmann 1983 [1969]: 100-106). It was the economist Albert Hirschman who convincingly claimed that it is not so much common values that integrate a modern society but the implemented and guarded institutional equipment of reinterpreting either-or conflicts into more-or-less conflicts (Hirschman 1994). The disruptive potential of a zero-sum game where total gain of a winner means total loss for the loser is 
changed according to the rules provided by a third uninvolved party (the institution, e.g. a court) into a negotiated outcome. In other words those institutions must protect the complexity and graduation of a conflict from techniques of radical simplification by force - power techniques that lead to either-or approaches or even deny the opponent the right to dispute altogether.

The question of re-establishing peace therefore has to be approached in the same basic way. The crucial question is which institutions societies and states have left after sustained violence in order to re-embed conflict, and what capacities they have to build new ones. Societies after conflict must ensure that vital state tasks such as providing security and opportunities are not taken over by organised groups; they must prevent organisers of violence accessing resources; they must re-establish a legitimate monopoly of violence; and they must, finally, provide social coherence by establishing the institutions that integrate a society. These are complex tasks that require time and resources that most post-war societies do not have. The odds that this will happen without external intervention, relying solely on societal self-organisation, are very slim.

A brief overview over the cases presented in this volume shows that none of the post-war societies has until now managed to complete these tasks. All of them are still struggling with the many obstacles on the road to institutionalised peace, and where stability has been achieved, it has come at a price.

Armenia has been the most stable of the Transcaucasian states. The reason for this may be found in the ethic homogeneity and in the perception of a constant threat of national disaster that is both an integral part of modern Armenian identity and a political reality in the post-Soviet period. The price for the relative stability has been the externalisation of conflict, a price that both Armenians and Azeris had to pay. As an Armenian taxi driver in Yervan in the summer of 2000 put it when complaining about the recently aggravated problem of high-level political violence: 'Our problem is our ethnic homogeneity. We have only each other to blame and fight with.' ${ }^{8}$

In former Yugoslavia, reconstruction of statehood has so far been borrowed from the international community, which has invested considerable military and financial resources. The experience in Kosovo teaches us that the task is extremely difficult. Despite the presence of an overwhelmingly and widely accepted military force, and despite the impressive financial resources the European Union is committing to the rebuilding of a working state structure in Kosovo, Bosnia and Macedonia, only extremely benevolent observers would think that the operation has ended successfully. On the contrary - external forces are getting more and more deeply involved in the Balkans, and the chances are very high that conflicts will very soon remerge, were it not for the presence of the externals.

With regard to Kosovo, is very doubtful whether those groups that have successfully organised violence are willing to engage in meaningful state building efforts. The fact that the UCK has been deeply involved in a criminal economy 
makes it rather unlikely that this group will become the backbone of the state. In addition, Mappes-Niediek's Chapter 5 in this volume reminds us that Kosovars in general place their loyalty and their efforts much more in the extended family than the state. It is not hard to predict that the KFOR and the UN administration of Kosovo will sooner or later have to engage this problem, thereby risking becoming regarded as an occupying force rather than as protector.

The case of Bosnia also provides an important lesson. External intervention does not automatically pave the way for state reconstruction. As Gosztonyi's Chapter 2 in this volume demonstrates, intervention can actually contribute to a diffusion of power. The intervening force's efforts at establishing a monopoly of violence and at holding responsible the local strong men actually makes it rational for local elites to appoint weak leaders and to create an institutional 'jungle' in order to diffuse responsibility. In time, the local elite loses the ability to commit themselves and to deliver - both preconditions for instability and contradictory to the fundamental task of re-embedding conflict. Such counterstrategies of local networks prove effective unless intervening states or alliances are willing to establish a long-lasting protectorate and resume semi-colonial responsibilities a task that would clearly overstretch the capacities of the international community, even if it wished to do so.

Looking back at a decade of coming to terms with conflict in post-socialist Yugoslavia and the Caucasus, the picture is, as always, neither one thing nor another. On the one hand, all conflicts in the regions are for the time being frozen, with the exception of Chechnya. However, stability in the Caucasus is precarious, as it is, despite the commitment of the international community, in the Balkans. Most successor states of the empires are still far from having established a legitimate monopoly of violence-either it is defunct and working only when the state happens to drive past, or it is rented out from international organisations. And lastly, in many cases the networks of patronage of the late socialist state took over and are in effect running the remnants of the state. Therefore, it would be very wrong to believe that trading the imitation of socialism for the imitation of democracy spares the new states (or the international organisations in charge of implementing state institutions) from the pitfalls of weak statehood.

\section{And finally: a word on methodology}

It has been argued here that violence and stability in post-socialist societies cannot be explained without taking into consideration the hybrid institutional framework of the locality under consideration, since it is the local 'traditional' institutions that account for the remarkable variance revealed by comparing the potential hot spots in Yugoslavia and the Caucasus. Such local institutions process the impact of various 'risk factors' and determine whether a society deals with these factors in a non-violent way. Violence, and especially internal and 
common violence, is organised at the local level. Consequently, it has been argued here that the local institutional framework is the most promising level of analysis. This is not to say that the institutional framework of a polity is not subject to external influences, clearly the weakening of the central state hierarchies; the (intended or unintended) effects of the policies of third countries; the (intended or unintended) effects of the policies of international organisations and spillover of violence ('bad neighbourhoods') all impact upon the incentive structures of local actors. External influence is important, but it needs to be investigated from the local perspective.

How can such micro-politics of violence be captured?

Analytical narratives dealing with the organisation of violence may profit from a multi-disciplinary approach. Since 1980, quantitative probabilistic studies have made significant progress in identifying risk factors. ${ }^{9}$ Economic deprivation, a high level of dependence on primary commodity exports, ethnic composition, terrain, previous conflicts, perceived and real grievances and 'bad neighbourhoods' are among the most prominent risk factors. Analytical narratives should watch out for such factors. One should, however, be aware that risk factors do not automatically turn into violence. Statistically measured probabilities inform about risks; but they do not show anything about causal links. For organised violence to emerge, it takes certain social situations in which actors think that the relative costs of violence are lower than the relative costs of nonviolence. Otherwise actors would not engage in the organisation of violence. In other words, the organisation of violence depends on the incentive and opportunity structure in which actors are locked. Often, the most relevant of these structures are not official state institutions, but informal and traditional institutions in the shadow of the façade of statehood. Detecting these requires an intimate knowledge of the local. Conducting traditional ethnographical fieldwork captures unofficial institutions, networks, norms and values systems that help examine local social settings, in which the official (normative) story conceals rather than reveals the 'real' story of why actors act.

To what extent can insights, produced by such a research design, be generalised? What is the potential contribution to theory building of an approach that focuses on the institutional framework of a society? Such an approach would produce more than a story and less than a theory. Such a research strategy would hardly provide the 'parsimonious, elegant models with a high prediction power' of which the political scientists of the 1970s and 1980s dreamed. It would also not produce yet another account of how violence emerged in a specific time in a specific place under specific circumstances. The level of abstraction stops halfway: the 'causes' for violence or stability cannot be generalised, since violence is a strategy that, in principle, can be chosen in every social situation. However, it is possible to generalise aspects of the process of organising violence and stability. Some of these have been presented in this chapter. 


\section{Institutions and the organisation of stability and violence}

\section{NOTES}

1 For a useful overview of factors which can increase the risk for ethnopolitical violence, see van Evera (1994); Brown (1997); Gurr and Harff (1995).

2 The fact that institutions usually function within the values and belief systems of a society, i.e. are 'morally embedded' (unlike the institutions of markets of violence), is usually not considered in purist economic definitions of institutions. For the stabilising effect of moral embedding even for commodity markets see Elwert (1989: 459); compare also Norbert Elias' concept of internalised norms as conditions for establishing social space devoid of violence ('gewaltfreie Räume', Elias 1992 [1969]: 312-336).

3 It was Lewis Coser's congenial reading and further development of Georg Simmel's approaches to social conflict that laid the ground for an understanding of the significance of conflict and its institutionalisation for the dynamic cohesion and development of society (Coser 1956).

4 This pattern is also applicable to those seemingly authoritarian post-socialist states: if the state is not directly and openly involved in the control of civil institutions (like in Serbia under Milosovic) it necessitates them, just like trade and business, to seek the (illegal) patronage of state institutions. The notion that Command States - to borrow a term developed by Elwert in African case studies - are often weak states in an institutional sense is contradictory only at first sight. According to Elwert's definition, '[t]he Command State is a system of politics and administration characterised by the primacy of present authority in daily life interaction and an ambiguous relation with legal norms, which however define the overall power sharing within the apparatus' (Elwert 2001b: 420). If state institutions are not running in accordance with their own norms - if an only formally democratic or socialist government is, for example, relying entirely on the 'power ministries' (the military, police or secret services) for control and in its legitimacy is relying on informal networks of patrons distributing state resources - they may be considered 'weak'. As in the case of the late socialist states the rules providing stability are borrowed from other institutions.

5 For a differentiation of official, informal and criminal economy on a global scale, see Lock (2001).

6 The term was developed in Mediterranean anthropology (Banfield 1958) and has been criticised as normative derogatory. The concept was, however, applied to analyse family-state relations in Serbia (Simic 1991).

7 For the time being women and children did not play a decisive role in the organisation of violence in the Caucasus and former Yugoslavia. The appearance of groups of female fighters in the course of some conflicts (like, for example, the 'Anahit'-detachment in Nagorno-Karabakh) is the exception to the rule and not a widespread social phenomenon with an impact on the organisation of violence.

8 Conversation with Koehler in June 2000, as remembered.

9 Prominent projects are, among others, the Correlates of War Project (cf. Singer and Small 1994); the State Failure Project (cf. Gurr, Harff and Marshall 1997); the Polity Data (cf. Jaggers and Gurr 1995); the Minorities at Risk (cf. Gurr 1993); The Economics of Political and Common Violence. The World Bank Development Economic Research Group DECRG. (cf. www.worldbank.org/research/conflict/index.htm). The key paper from this project is Collier and Hoeffler (2001). 


\section{REFERENCES}

Banfield, E. (1958), The Moral Basis of a Backward Society (Illinois).

Brown, M. E. (1997), 'The causes of internal conflict: an overview' in M. Brown, O. Coté, S. Lynn-Jones and S. E. Miller (eds), Nationalism and Ethnic Conflict. An International Security Reader (Cambridge, MA and London), 3-26.

Brubaker, R. (1994), 'Nationhood and the national question in the Soviet Union and postSoviet Eurasia: an institutionalist account', Theory and Society, 23:1, 47-78.

Bunce, V. (1999), Subversive Institutions. The Design and the Destruction of Socialism and the State (Cambridge).

Collier, P. and A. Hoeffler (2001), Greed and Grievance in Civil War, www.worldbank. org/research/conflict/papers/greedandgrievance.htm (accessed 12 January 2002) (Washington, DC).

Coser, L. A. (1956), The Functions of Social Conflict (London).

Elias, N. (1992 [1969]),Über den Prozeß der Zivilisation. Soziogenetische und psychogenetische Untersuchungen. Wandlungen der Gesellschaft. Entwurf zu einer Theorie der Zivilisation, II (Frankfurt/M.).

Elwert, G. (1989), 'Nationalismus und Ethnizität. Über die Bildung von Wir-Gruppen', Kölner Zeitschrift für Soziologie und Sozialpsychologie, 3, 440-464.

Elwert, G. (2001a), 'Kühl, hochvernünftig und lernfähig. Wie terroristische Gruppen unter dem Dach von Ideologiefirmen effizient arbeiten und Attentäter heranziehen/ Typologische Einordnungen von Georg Elwert', Frankfurter Rundschau, online edition, www.asyl-rlp.org/aktuell/terrorfr.html (accessed 11 January 2002) (20 October).

Elwert, G. (2001b), 'The Command State in Africa. State deficiency, clientelism and power-locked economies', in S. Wippel and I. Cornelssen (eds), Entwicklungspolitische Perspektiven im Kontext wachsender Komplexität. Forschungsberichte des BMZ , 128 (Bonn), 419-452.

Gurr, T. R. (1993), Minorities at Risk (Washington, DC).

Gurr, T. R. and B. Harff (1994), Ethnic Conflict in World Politics (Boulder, CO).

Gurr, T. R., B. Harff and M. G. Marshall (1997), 'Codebook: internal wars and failures of governance, 1954-1996', State Failure Task Force, online publication, www.bsos. umd.edu/cidcm/stfail/index.htm (accessed 12March 2001).

Hann, C. (1996), 'Introduction. Political society and civil anthropology', in C. Hann and E. Dunn (eds), Civil Society. Challenging Western Models (London), 1-26.

Hedges, C. (1996), 'War-bred underworld threatens Bosnian peace', New York Times (1 May), 8.

Hirschman, A. O. (1994), 'Wieviel Gemeinsinn braucht die liberale Gesellschaft?', Leviathan, 2, 293-304.

Jaggers, K. and T. R. Gurr (1995), 'Tracking democracy's third wave with Polity III data', Journal of Peace Research, 31:4, 469-482.

Jamieson, A. and A. Silj (1998), Migration and Criminality: the Case of Albanians in Italy (Rome: Consiglio Italiano per le Scienze Sociali and Centre for European Migration and Ethnic Studies) (November).

Koehler, J. (1999), 'The school of the street: organising diversity and training polytaxis in 
a (post-) Soviet periphery', Anthropology of East Europe Review, Special Issue: Reassessing Peripheries Post-Communist Studies, 17:2, 9-52, http://condor.depaul. edu/ rrotenbe/aeer/aeer17_2.html.

Koehler, J. (2000), Die Zeit der Jungs. Zur Organisation von Gewalt und der Austragung von Konflikten in Georgien, 64 (Münster, Hamburg and London).

Lock, P. (2001), Ökonomien des Krieges. Ein lange vernachlässigtes Forschungsfeld von großer Bedeutung für die politische Praxis, www.peter-lock.de/Neuer\%20Ordner/Kriegs\% 9Akonomien2.html (accessed 12 January 2002).

Luhmann, N. (1983 [1969]), Legitimation durch Verfahren (Frankfurt/M.).

Schork, K. (1994), 'Sarajevo gangsters die as they lived - by the gun', Reuters Information Services ( 5 January), online edition.

Schwandner-Sievers, S. (1998), 'Wer besitzt die "Lizenz zum Töten” in Albanien? oder: Fragen ur Gruppensolidarität und Gewaltlegitimation in einer "anderen Modernisierung”, in J. Koehler and S. Heyer (eds), Anthropologie der Gewalt. Chancen und Grenzen der sozialwissenschaftlichen Forschung (Berlin), 71-88.

Simic, A. (1991), 'Obstacles to the development of a Yugoslav national consciousness: ethnic identity and folk culture in the Balkans', Journal of Mediterranean Studies, 1:1, $18-36$.

Singer, J. D. and M. Small (1994), Correlates of War Project: International and Civil War Data, 1816-1992 (Ann Arbor).

van Evera, S. (1994), 'Hypotheses on nationalism and war', International Security, 18: 4 , 5-39.

Willerton, J. P. (1992), Patronage and Politics in the USSR (Cambridge).

Wood, P. (2000), 'Gangster's life of Serb warlord', BBC News (15 January), online, http:// news.bbc.co.uk/hi/english/world/europe/newsid_605000/605266.stm (accessed 11 January 2002).

Zürcher, C., J. Koehler and P. Baev (2002), Internal Violence in the Caucasus, study prepared for The World Bank Development Economic Research Group (DECRG), The Economics of Political and Common Violence (Washington, DC). 
Jan Koehler and Christoph Zürcher - 9781526137586 Downloaded from manchesterhive.com at 04/26/2023 01:58: ๑8PM via free access 